\title{
USING AND VERIFYING SEEDCHASER MODEL TO EVALUATE THE ROLE OF TILLAGE MACHINES IN SEED WEED DISTRIBUTION IN NEW EL-SALHIA REGION
}

\author{
Khater, M. M. I.*
}

\section{ABSTRACT}

The vertical distribution of weed seeds following tillage using SeedChaser Model for describing the vertical redistribution of weed seeds following the selected (a) different tillage implements ' and (b) the initial seed distribution values. In order to validate of SeedChaser model, eight tillage implements were examined for estimation of the model including the conventional treatment which widely used in New El Salhia region (chiseling twice). The tillage implements were tested in field experiments and compare with data collected from estimation of the model. Tillage implements that were extrapolated were coded in the Java programming language which predicts the movement of weed seeds following a user selectable sequence of tillage events. The resulted data indicated that using Paraplow and disc plow showed a weed infestation which increased in few weeks, compared with other tillage techniques. While a significant reduction in weed infestation resulted during conventional tillage, and chisel plow treatments. In the $1^{\text {st }}$ period on $22^{\text {nd }}$ of June, no remarkable weeds infestation was happened, dry mass of the weeds was less than 45 $\left(\mathrm{g} / \mathrm{m}^{2}\right)$ in all treatments. While on $22^{\text {nd }}$ of July, a remarkable existence of the weeds was found, it was less than $40\left(\mathrm{~g} / \mathrm{m}^{2}\right)$ for conventional, chisel, mouldboard and rotovator implements, while it was more than $64\left(\mathrm{~g} / \mathrm{m}^{2}\right)$ for both paraplow and disc plow. Through the last period on $22^{\text {nd }}$ August the weed infestation was clearly found, the paraplow and disc plow were represented the higher values as compared with the other techniques, it was more than $114\left(\mathrm{~g} / \mathrm{m}^{2}\right)$, while the conventional tillage treatment was the lowest value by less than $15\left(\mathrm{~g} / \mathrm{m}^{2}\right)$. The crop yield values under studied simulated implements were ranked as conventional treatment > chisel plow > mouldboard plow > rotovator > rigid tine spike > power harrow > disc plow > paraplow.

\section{*Soil Conservation Department, Desert Research Center, Cairo, Egypt}


The obtained results revealed that the crop yield values ranged between 20410 to 39260 under studied treatments. Polynomial equations were computed for the measured and estimated data for all experimented implements which showed that $R^{2}$ varied from 0.5673 to 0.9368 with no exceptions for non significant relations. This clearly means acceptable application of SeedChaser model for forecasting the distribution of weed seeds under El Salhia location with the applied implements.

Keywords: Weed seeds movement, SeedChaser and Conservation tillage.

\section{INTRODUCTION}

7 he SeedChaser model was proposed to use 1-cm spacing field measurements to characterize the movement of weed seeds in soil as a consequence of tillage. Other studies used extrapolation techniques to arrive at finer intervals. This model was developed in JAVA programming language which is simple to use and is publicly available via the Internet (http://www.ars.usda.gov/mwa/ncscrl) The vertical weed seeds distribution through the soil profile is one of the important factors which controlling weed emergence. Burial depth directly impacts the ability of seeds to germinate and emerge successfully (George and Frank, 2006). To develop an accurate weed emergence model, the distribution of seeds following tillage implement passes was needed. The vertical movement of weed seeds as a consequence of tillage implements was the primary cause of alterations in vertical seed distributions (Buhler et al., 1997). Weed seeds can also be moved by rain drop impact, soil organisms, or entry via infiltration through large macropores or cracks. However, the effects of these factors often are small relative to tillage disturbances (Govers $\boldsymbol{e t}$ al., 1996). Soil tillage stimulates germination of buried seed populations (Al-Kaisi and Yin 2004). Tillage also alters the soil physical structure, which results in different microclimate conditions that impact seed germination (Stahl et al., 1999). Often only 5\% of the weed seedweeds produce seedlings each year (Forcella et al., 1992), indicating that a large seed reservoir within the soil remains subject to various tillage events. The major point is on weed seed movement following the use of conservation tillage or reduced tillage intensity 
implements. Even though conservation tillage implements are not aggressive as traditional implements such as moldboard plows and subsoilers. While reduced tillage intensity leads to increased numbers of surface weed seeds due to lack of deep incorporation (Yenish et al., 1992). However, the impact of reduced tillage on seed movement within the shallow surface $(0-5 \mathrm{~cm})$ horizon was examined rigorously and is critical because shallow depths are more important for weed emergence than deeper depths due to minimal emergence from deeply buried seeds (O'Donovan and McAndrew 2000). The ability to model the combined effect of tillage implement passes on seeds buried in the shallow surface $(0-5 \mathrm{~cm})$ is compiled to mechanistic models of weed seedling emergence. Many models have been examined until these shallower intervals and extrapolated by curve fitting or linear approximation (Mohler et al., 2006). In addition, fast Fourier transforms (Mead et al., 2003) and probability density functions (Marshall and Brain, 1999) have been utilized to model seed movement as well. These mathematical extrapolations are only valid if the behavior is similar among the depths. SeedChaser model was verified using the results of (Rahman et al. 2000) for the vertical weed seeds distribution following power harrowing. Initial seed distribution for an undisturbed soil was used to set the initial seed distribution before tillage in SeedChaser. The power harrowing did not significantly redistribute the vertical profile of seeds. This was confirmed by the developed model, and it accurately predicted the vertical distribution of seeds. Differences among soil types have been ignored in SeedChaser. The developed model is viewed as a tool for common agricultural soils. (Swanton et al. 2000), observed that tillage distribution is different in sandy soil versus finer texture soils. Whether these differences were due to soil type or other management factors remain unknown, which may be rendered to variation in soil porosity.

Therefore, the present research aimed to provide detailed data on conservation tillage implements, in addition to traditional implements, and to develop a fine-scale tracking model for weed seeds and soil particle movement using depth increments of $(1 \mathrm{~cm})$. 


\section{MATERIALS AND METHODS}

A private farm in New El Salhia was selected to carry out the field

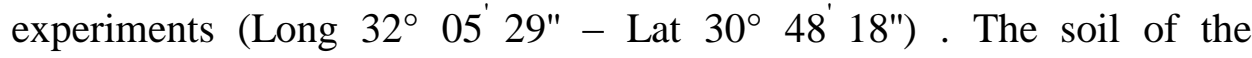
experimental plots was classified as sandy loam (63.49\% sand, $29.07 \%$ silt and $7.44 \%$ clay). Particle size distribution of soil was determined according to (Klute 1986). Experiments were performed in an infested site by annual weeds such as Eleusineindica and cynodondactylon.

O-35 corn silage variety was used as an indicator plant in 2015, at a planting rate of $40 \mathrm{~kg} / \mathrm{ha}$. The irrigation system was applied using sprinkler irrigation.

Eight tillage implements were examined in this work and are summarized in Table (1) for estimation of the SeedChaser model including the conventional treatment which is widely used in New El Salhia region (chiseling twice). The outlined tillage implements used in this model were tested using the SeedChaser model to measure practically in field experiments and compare with data collected from estimation of the SeedChaser model including the conventional treatment used in this experiment. SeedChaser model was developed in JAVA and is publicly available via the Internet.

Table (1): Outline implements used in the SeedChaser model test.

\begin{tabular}{cc}
$\begin{array}{c}\text { Estimated } \\
\text { treatments }\end{array}$ & $\begin{array}{c}\text { Working depth } \\
(\mathbf{c m})\end{array}$ \\
\hline Traditional tillage (chiselling+ twice) & 15 \\
Chisel plow & 15 \\
Mouldboard plow & 20 \\
Disc plow & 20 \\
Paraplow(Sub-soiler) & 30 \\
Power harrow(Disk harrow) & 12 \\
Rigid tine (spike harrow) & 12 \\
Rotovator (rotary cultivator) & 10 \\
\hline
\end{tabular}

Tillage model for vertical weed seed distribution was named SeedChaser, initiated and developed by K. Spokas, F. Forcella, D. Peterson, D. Archer 
and D. Reicosky from (Agricultural Research Service. USDA-ARS, 803 Iowa Ave., Morris, MN, USA ). They developed a 1-D empirical vertical soil tillage particle distribution model with $1 \mathrm{~cm}$ grid spacing. The model predicts the vertical distribution of weed seeds following a user selected sequence of tillage cycles and an initial seed profile. Results of this model are particularly suited for weed seedling emergence modeling. This model was developed in JAVA, is simple to use, and is publicly available via the internet. (http://www.ars.usda.gov/mwa/ncscrl - Located in Products and Services) This work was supported by USDA-CSREES-NRI agreement number 2005-35320-15400.

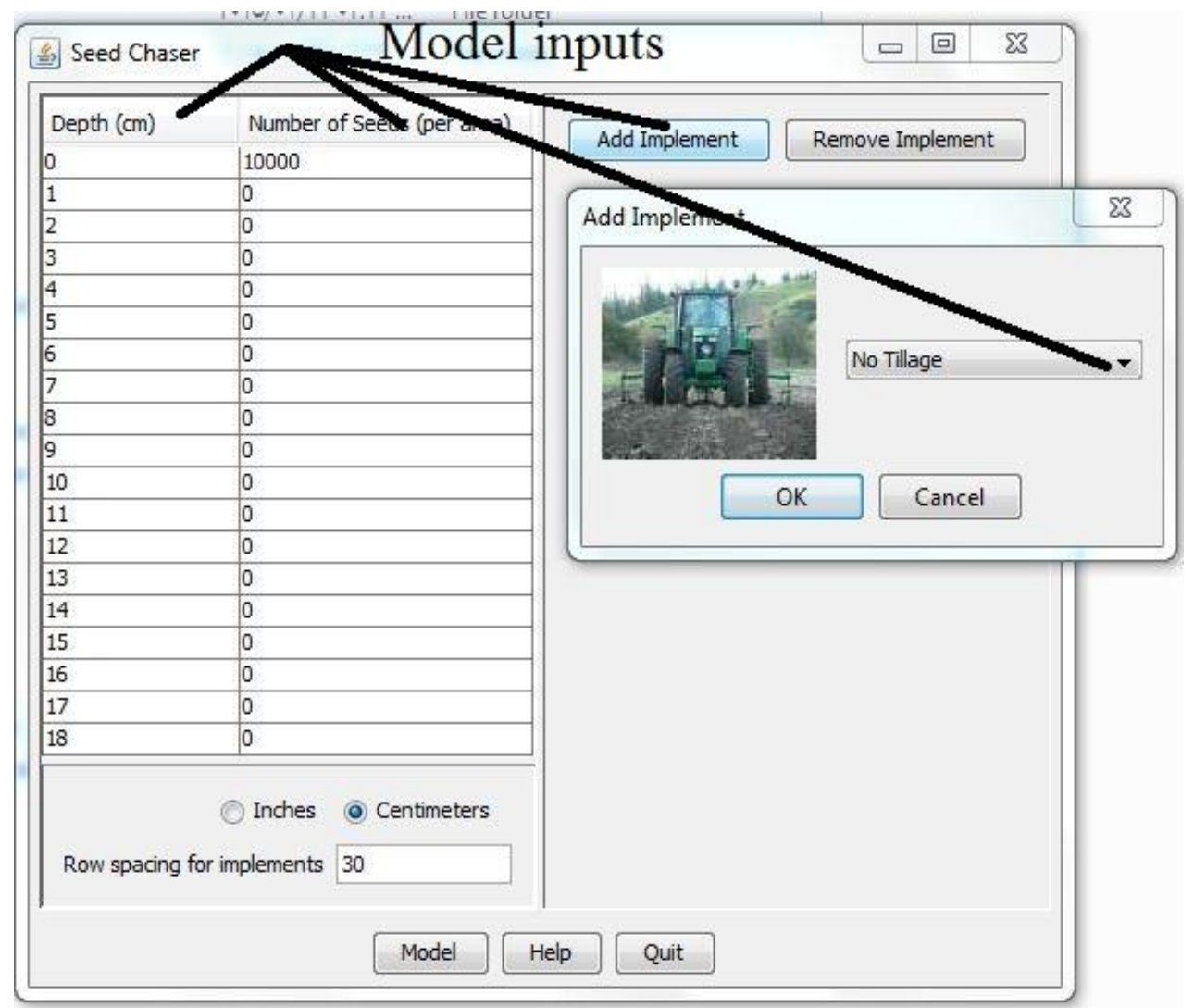

Fig. (1) The inputs of SeedChaser model.

in Fig. (1) The inputs of SeedChaser model were depth (cm), Number of seed weeds, adding the tillage implement, type of machine used. 


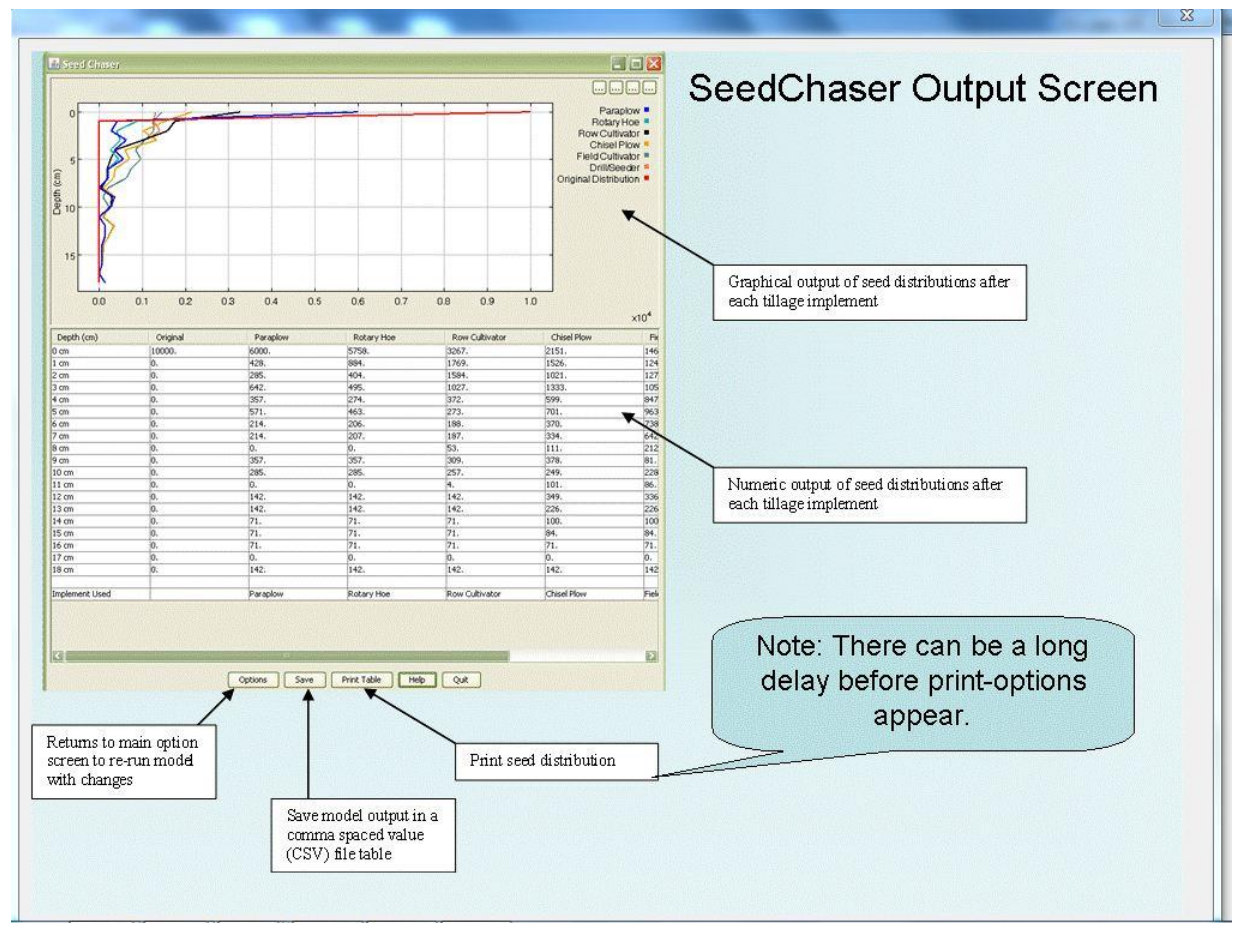

Fig. (2) The output items of SeedChaser model.

in Fig. (2) The output of SeedChaser model was a relation between the weed seeds distribution through the soil profile, according to the used tillage implement model. Resulting output is displayed numerically and graphically, and can also be saved to a file for subsequent analysis.

As to justify the applicability of the model to El Salhia soil conditions soil samples of the infested soil by weed seeds. a $10 \mathrm{~cm}$ diameter hole was created with a plastic auger until depth of $30 \mathrm{~cm}$. Typically, 5 replicates were conducted after each tillage implement (Mohler et al., 2006). In this manner the exact placement of each record was including vertical translocation of weed seeds. Then soil was cored by knife to $30 \mathrm{~cm}$ depth in the tested area by careful scraping with a hand trowel. Each cored sample was analyzed for each $1 \mathrm{~cm}$ of depth in the laboratory of plant protection institute (Zagazig branch) to classify and count each type of the weed seeds. Weed dry biomass was estimated by sampling the aerial part of the plants at three random square sampling areas in each plot. Squares had dimensions of $50 \mathrm{~cm}$. The dry weed mass were weighed and samples were oven dried at $220 \mathrm{C}$ for $48 \mathrm{~h}$. The samples were taken three times 
during the season, after $7\left(22^{\text {nd }}\right.$ June $), 30\left(22^{\text {nd }}\right.$ July $)$ and $60\left(22^{\text {nd }}\right.$ Aug $)$ days of planting.

\section{Benefit cost ratio (BCR) :}

Benefit cost ratio was calculated for each treatment and estimated, where: $\mathrm{BCR}=$ benefit cost ratio value; $\mathrm{TR}=$ Total revenue $(\mathrm{P} * \mathrm{Y}), \mathrm{P}=$ Price, $\mathrm{Y}=$ Yield tons/ha or $\mathrm{kg} / \mathrm{ha}, \mathrm{TC}=$ Total Cost $(\mathrm{FC}+\mathrm{VC}), \mathrm{FC}=$ Fixed costs, $\mathrm{VC}$ $=$ Variable costs.

\section{RESULTS AND DISCUSSION \\ Applied estimation of tillage implements by SeedChaser model:}

SeedChaser model was tested and validated for all tillage implements by inserting the number of weed seeds until the soil depth related to the tillage implement used for each treatment. Generally, there was good coordination between estimated (from SeedChaser model) and measured (by sampling) values as shown from $\mathrm{R}^{2}$ values with different rates of coorelation among the treatments. This finding indicate the model could be applied under El Salhia soils conditions with the used implements to expect the resulted weed seeds distribution. Data showed that, with conventional treatment (chiseling twice) and chisel plow implements disturbed weed seeds upper than $10 \mathrm{~cm}$ (Fig. 1), whereas the power harrow (disk harrow), rigid tine (spike harrow) and rotovator (rotary cultivator) disturbed weed seeds in the shallow sub surface. Regarding the mouldboard plow, disc plow and Paraplow (sub-soiler) they disturbed weed seeds below $10 \mathrm{~cm}$. The Paraplow and rigid tine implements had the lowest overall curved fits. This most likely was due to the probability of buried weed seeds being hit many times by a shear forces of the implements or potentially being disturbed by the side of soil shear action with weed seeds. However, despite this potential issue the model still successfully applicable in predicting the weeds seeds movements in the soil. Interpolated data for chisel plow, disc plow, paraplow and rotary cultivator were compared to the field data collected in this experiment. Despite these measures being lower for the interpolated data, but generally still predicted the overall shape of the weed seeds distribution. These results show the importance of these measurements to accurately predict weed seed distribution as imposed by tillage implements, particularly near the surface. Distribution curves were not necessarily 
smooth curves and generally the curved predictions illustrates the depth of more than $10 \mathrm{~cm}$ being a critical depth for the most tillage implements. This depth accumulated the highest number of weed seeds. That is due to the trench opening effect of the curved tillage implements blades and the weed seeds were able to fall to the base of this trench. This is one example of the critical depth phenomenon that might not be captured by averaging coarser depth intervals (e.g., Mohler et al., 2006). Even though this depth accumulated the most seeds, surface seeds were distributed predominately between 0 and $6 \mathrm{~cm}$ with the chisel plow, which is in agreement with the results from (Straicka et al. 1990).

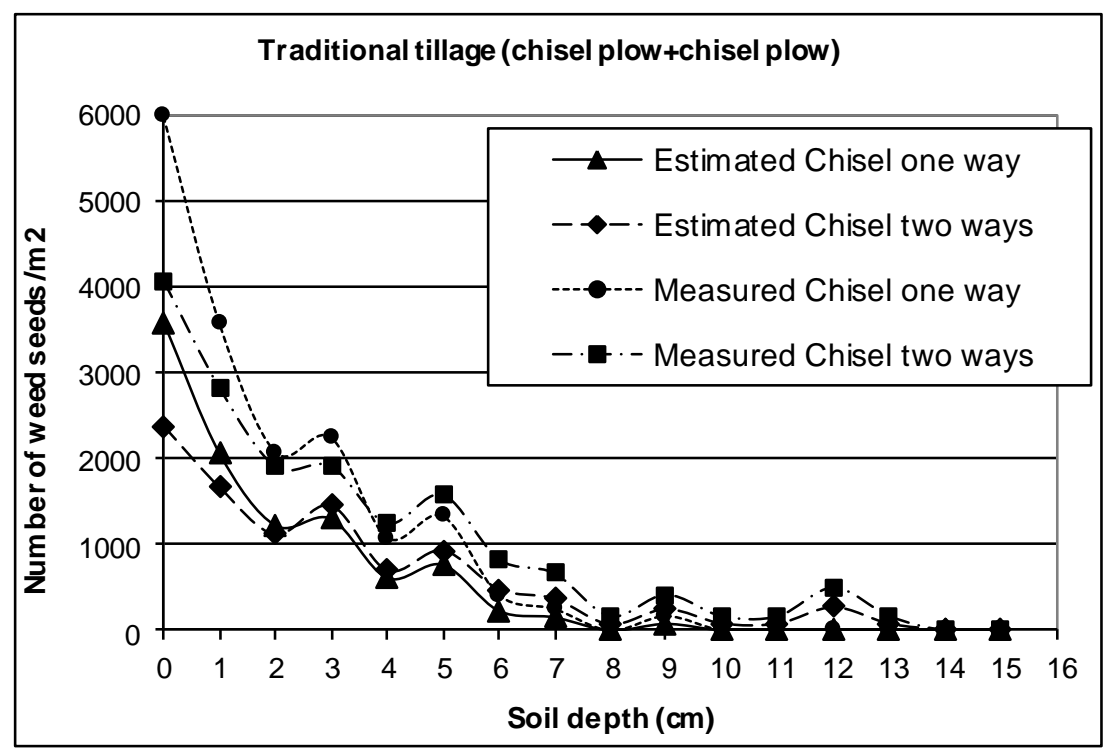

\begin{tabular}{|c|c|c|}
\hline Chisel plow (twice) & Polynomial Equation & $\mathbf{R}^{2}$ \\
\hline Estimated one way & $\mathrm{Y}=26.715 \mathrm{x}^{2}-568.96 \mathrm{x}+2821.5$ & 0.9086 \\
Estimated two ways & $\mathrm{Y}=14.399 \mathrm{x}^{2}-346.56 \mathrm{x}+2104.4$ & 0.9312 \\
Measured one way & $\mathrm{Y}=44.581 \mathrm{x}^{2}-954.33 \mathrm{x}+4771.1$ & 0.9155 \\
Measured two ways & $\mathrm{Y}=24.15 \mathrm{x}^{2}-576.83 \mathrm{x}+3492.1$ & 0.9368 \\
\hline
\end{tabular}

A- Traditional treatment (Chiselling twice)

In the conventional treatment, chiseling twice rise some most of weed seeds to the soil surface which could be vanished under the shading of major plants. While the rest of the seeds going deeply to sub-surface layer $(>10 \mathrm{~cm}$ ) and could not appear on surface. 


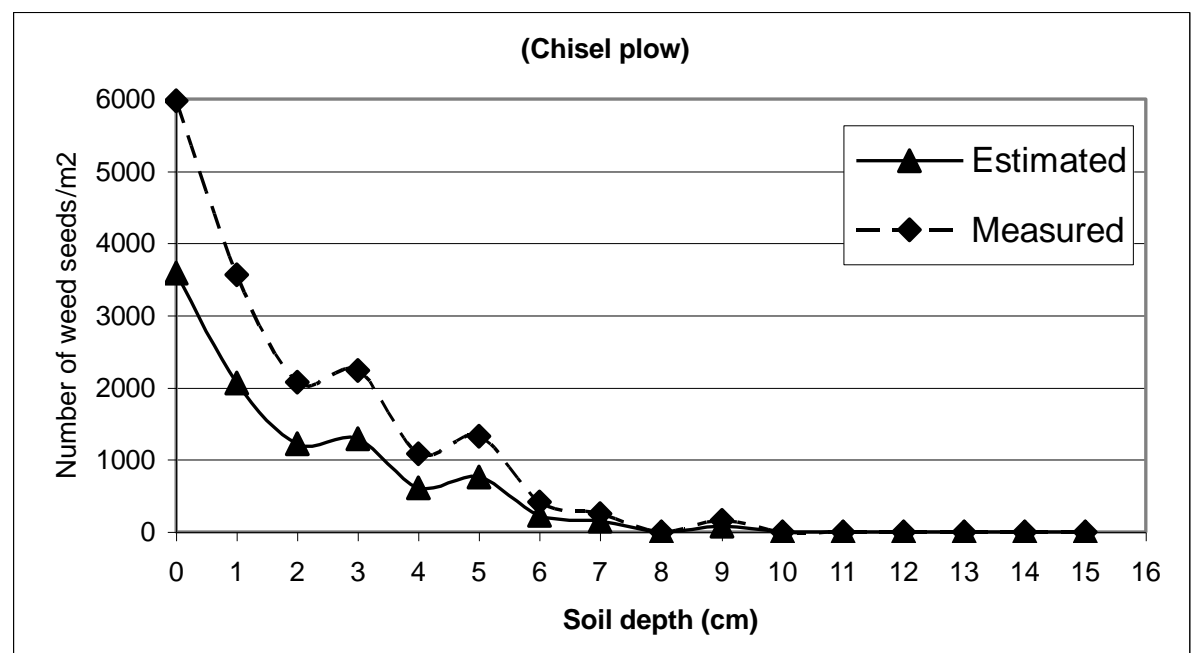

\begin{tabular}{|c|c|c|}
\hline Chisel plow & Polynomial Equation & $\mathbf{R}^{\mathbf{2}}$ \\
\hline Estimated & $\mathrm{Y}=26.715 \mathrm{x}^{2}-568.96 \mathrm{x}+2821.5$ & 0.9086 \\
Measured & $\mathrm{Y}=44.581 \mathrm{x}^{2}-954.33 \mathrm{x}+4771.1$ & 0.9155 \\
\hline
\end{tabular}

B-Chisel plow

In the chisel plow treatment, chisel plow seems to give the same trend like the traditional treatment

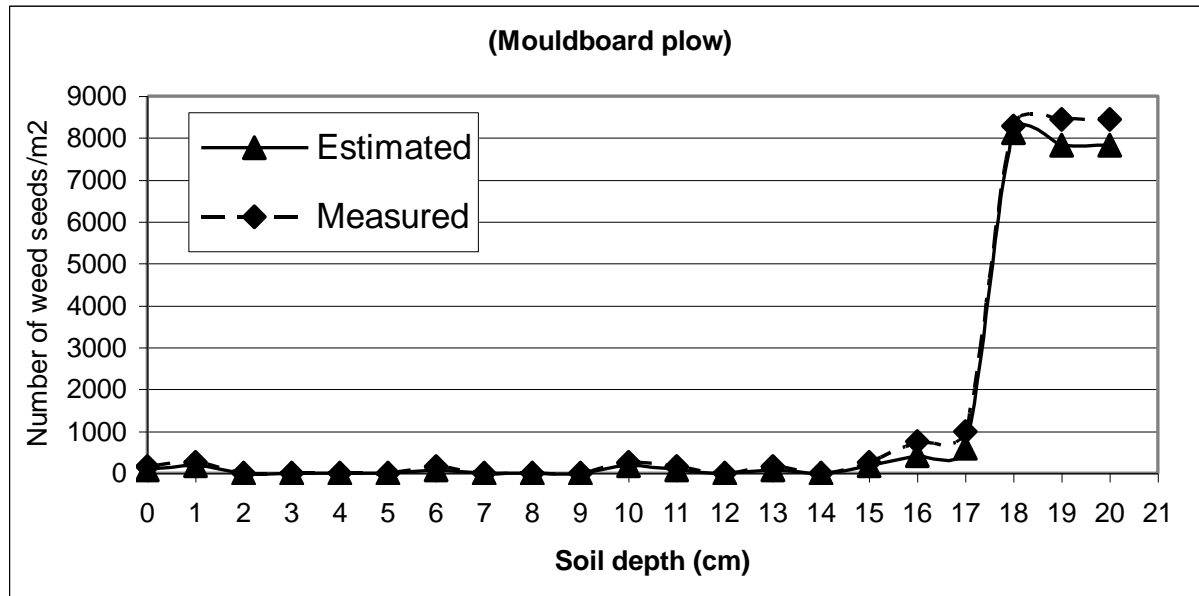

\begin{tabular}{|c|c|c|}
\hline Mouldboard plow & Polynomial Equation & $\mathbf{R}^{\mathbf{2}}$ \\
\hline Estimated & $\mathrm{Y}=47.66 \mathrm{x}^{2}-668.96 \mathrm{x}+1396.9$ & 0.7168 \\
Measured & $\mathrm{Y}=50.954 \mathrm{x}^{2}-713.22 \mathrm{x}+1517.3$ & 0.7450 \\
\hline
\end{tabular}

C-Mouldboard plow

In the mouldboard plow treatment, it seems to distribute weed seeds through the soil layers by increasing with soil depth. 


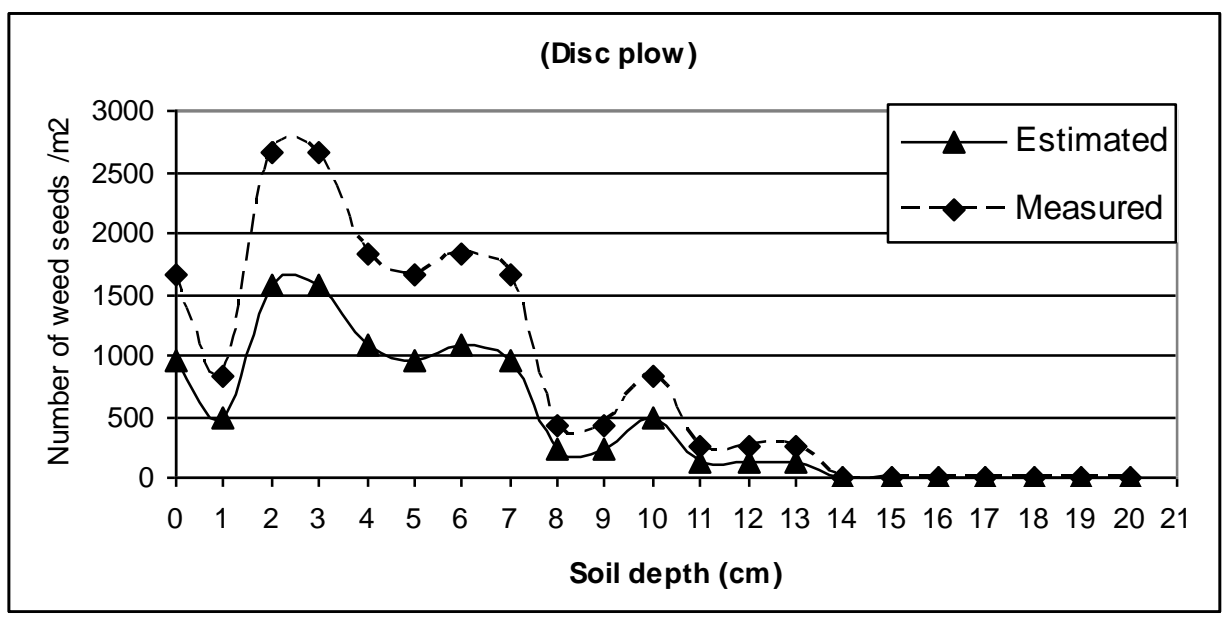

\begin{tabular}{|l|c|c|}
\hline Disc plow & Polynomial Equation & $\mathbf{R}^{\mathbf{2}}$ \\
\hline Estimated & $\mathrm{Y}=1.6883 \mathrm{x}^{2}-106.48 \mathrm{x}+1309.9$ & 0.7004 \\
Measured & $\mathrm{Y}=2.6899 \mathrm{x}^{2}-177.44 \mathrm{x}+2224.9$ & 0.7063 \\
\hline
\end{tabular}

\section{D-Disc plow}

In the disc plow treatment, it seems to leave the major amount of weed seeds on surface layers $(2,6 \mathrm{~cm})$ while the rest of the seeds were distributed homogenously in the deeper layers. This behavior could give a chance to lately grow of seeds after seeding period which could compete with sorghum in nutrients and water.

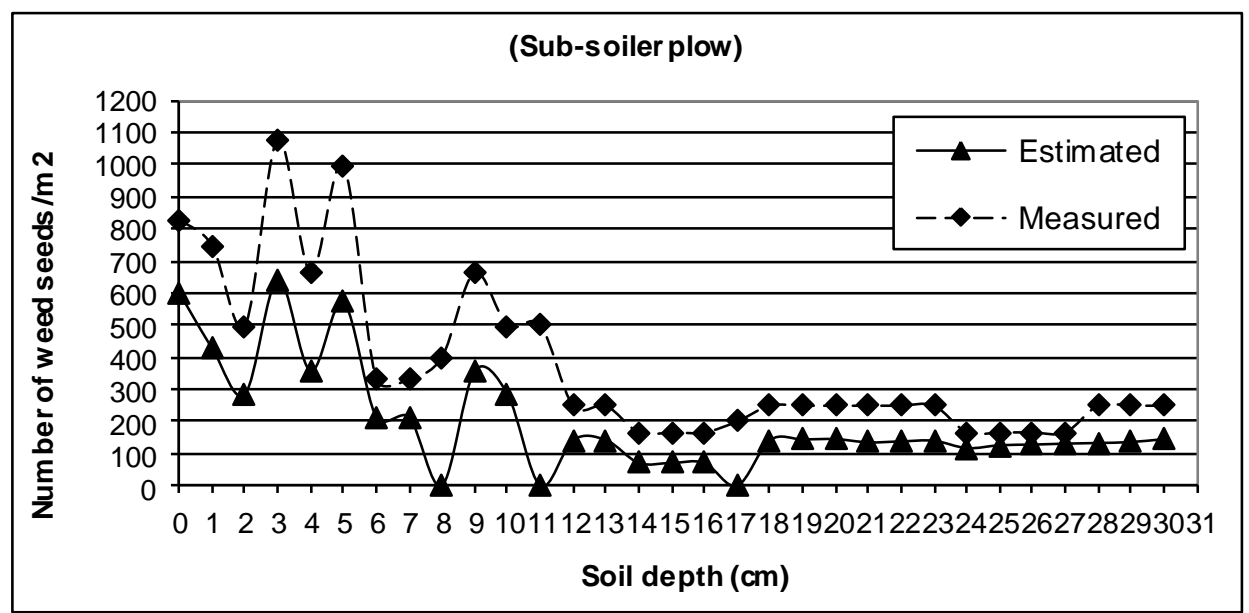

\begin{tabular}{|c|c|c|}
\hline Sub-soiler & Polynomial Equation & $\mathbf{R}^{\mathbf{2}}$ \\
\hline Estimated & $\mathrm{Y}=1.1501 \mathrm{x}^{2}-45.885 \mathrm{x}+537.82$ & 0.6310 \\
Measured & $\mathrm{Y}=1.3157 \mathrm{x}^{2}-60.316 \mathrm{x}+878.94$ & 0.6916 \\
\hline
\end{tabular}

E-Paraplow (Sub-soiler) 
In the Paraplow treatment, it seems to leave most of the weed seeds on surface and imbedded the rest in the subsurface layers $(5-10$ and $>10 \mathrm{~cm})$, so the shallow layers $(3,5$ and $9 \mathrm{~cm})$ could compete with seedlings on nutrients and water as well.

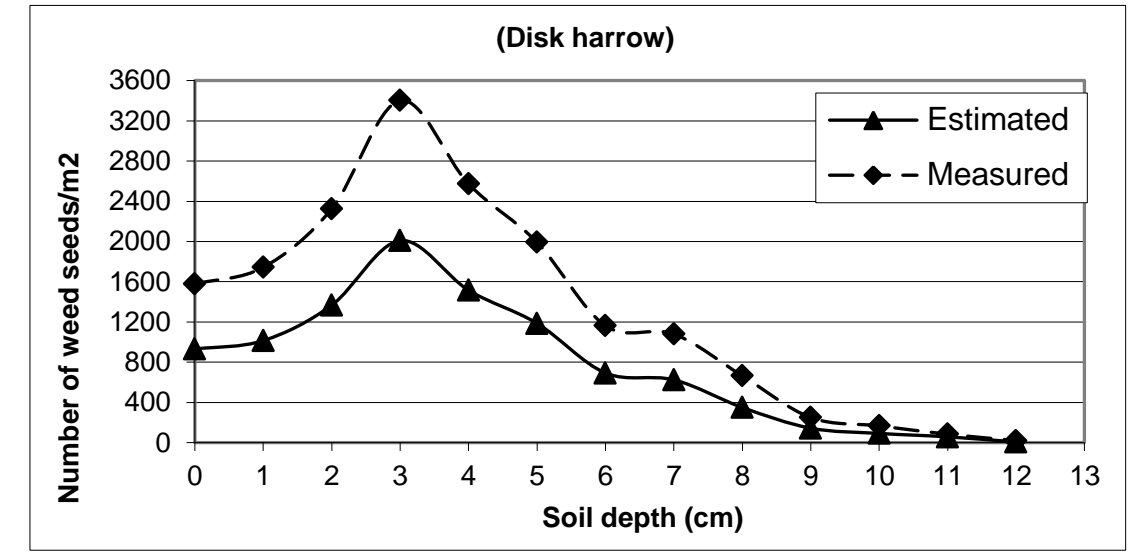

\begin{tabular}{|c|c|c|}
\hline Disk harrow & Polynomial Equation & $\mathbf{R}^{\mathbf{2}}$ \\
\hline Estimated & $\mathrm{Y}=-13.652 \mathrm{x}^{2}+32.388 \mathrm{x}+1256.1$ & 0.7245 \\
Measured & $\mathrm{Y}=-23.287 \mathrm{x}^{2}+57.1 \mathrm{x}+2132.1$ & 0.7294 \\
\hline
\end{tabular}

F-Power harrow (disk harrow)

In the power harrow treatment, the majority of the weed seeds were found in sub-surface layer $(0-5 \mathrm{~cm})$, while the rest were found in deeper layers (5 -10 and > 10cm), so competition between weeds and sorghum seedlings could be affect the yield.

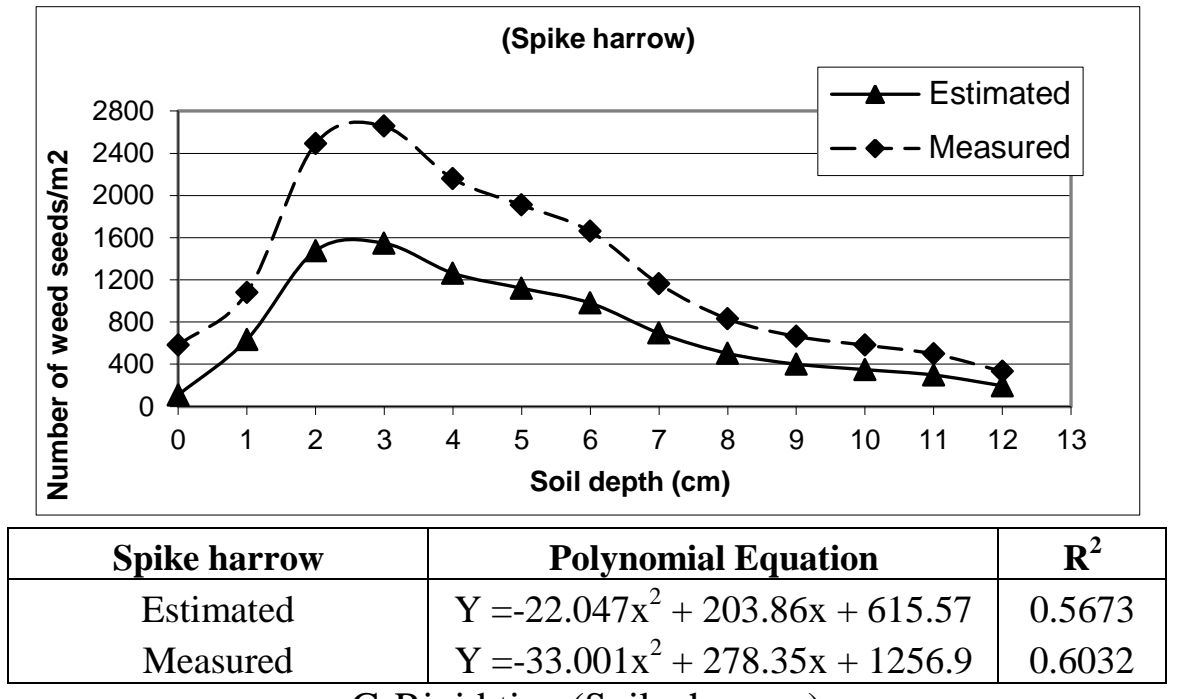

G-Rigid tine (Spike harrow) 
In the rigid tine treatment, it seems to imbedded the majority of the weed seeds in sub-surface layer $(2-7 \mathrm{~cm})$ which could easily enhance weed growth which could competed with sorghum yield.

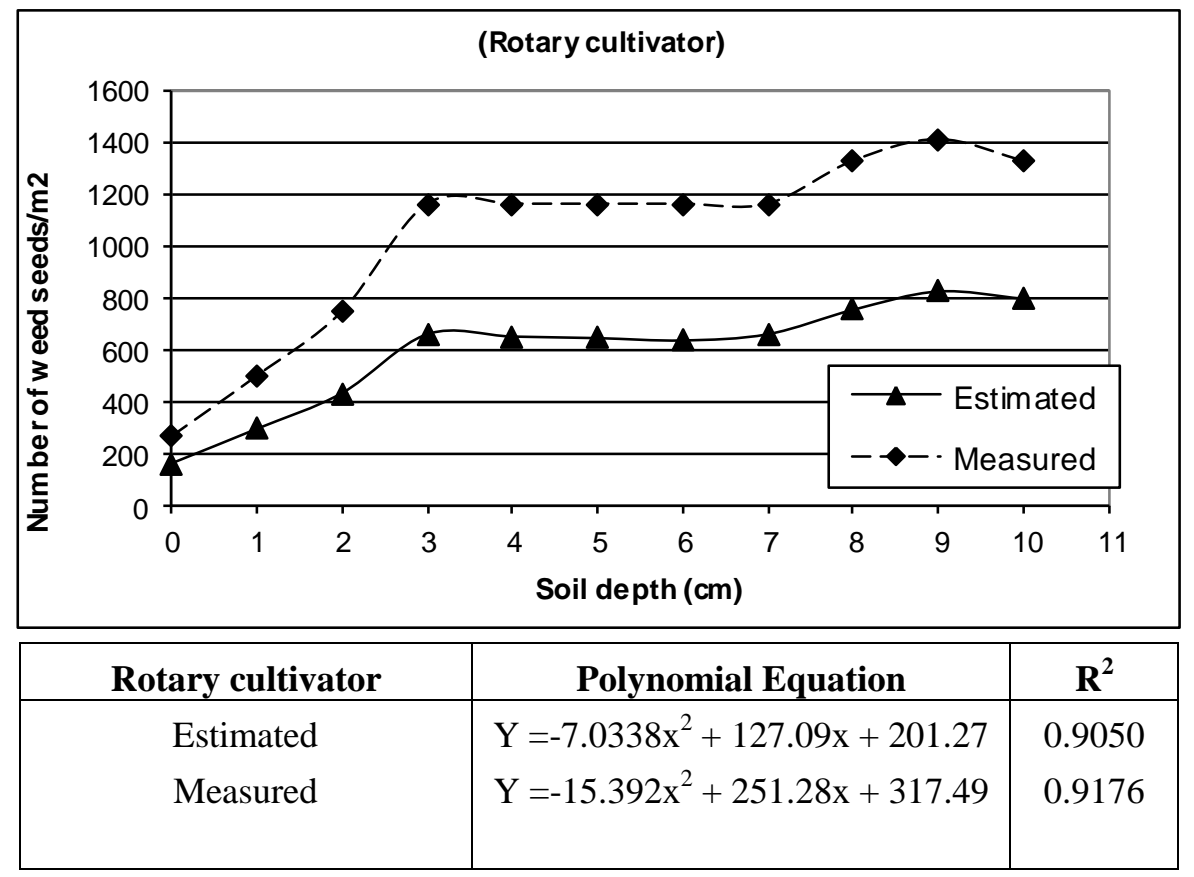

H-Rotovator (Rotary cultivator)

In the rotovator treatment, Most of the weed seeds were imbedded in the near sub-surface layer $(>3 \mathrm{~cm}$ ) which quite sure could competed with sorghum crop..

Fig. 3. Comparison of measured distribution patterns from 0 to $18 \mathrm{~cm}$ following tillage compared to the results from SeedChaser for (A) conventional treatment, (B) chisel plow, (C) Mouldboard plow, (D) Disc plow, (E) Paraplow, (F) Power harrow, (G) Rigid tine, and (H) Rotovator.

\section{Dry weed mass:}

Fig. (3), table (2) shows that when using both of Paraplow (sub-soiler) and disc plow, weed infestation was dramatically increased and appeared in few weeks later due to the left of major weed seeds near the soil surface, which clarify that the problem persisted throughout the whole growing period as compared with other tillage techniques. While a significant reduction in weed infestation during conventional tillage, and chisel plow treatments was occurred due to impeding of the major weed 
seeds in the sub-surface layer which had not chance to grow on soil surface. When using power harrow (disk harrow), rigid tine (spike harrow) and rotovator (rotary cultivator) there were also serious weed problems during the period of crop development due to the weed seeds distribution along the whole soil layers. Regarding the biomass of weed seeds in the treatments it was noticed that, in the $1^{\text {st }}$ period on $22^{\text {nd }}$ of June, no remarkable weeds infestation was happened, dry mass of the weeds was less than $45\left(\mathrm{~g} / \mathrm{m}^{2}\right)$ in all treatments. During the period of the corn silage production on $22^{\text {nd }}$ of July, a remarkable existence of the weeds was found, it was less than $40\left(\mathrm{~g} / \mathrm{m}^{2}\right)$ for conventional, chisel, mouldboard and rotovator implements, while it was more than $64\left(\mathrm{~g} / \mathrm{m}^{2}\right)$ for both paraplow and disc plow. Finally, through the last period of the field operations and before harvesting on $22^{\text {nd }}$ August the weed infestation was clearly found, the paraplow and disc plow were represented the higher values as compared with the other techniques, it was more than $114\left(\mathrm{~g} / \mathrm{m}^{2}\right)$, while the conventional tillage treatment was represented by less than $15\left(\mathrm{~g} / \mathrm{m}^{2}\right)$. Data collected were similar as clarified by (Islam et. al 2007).

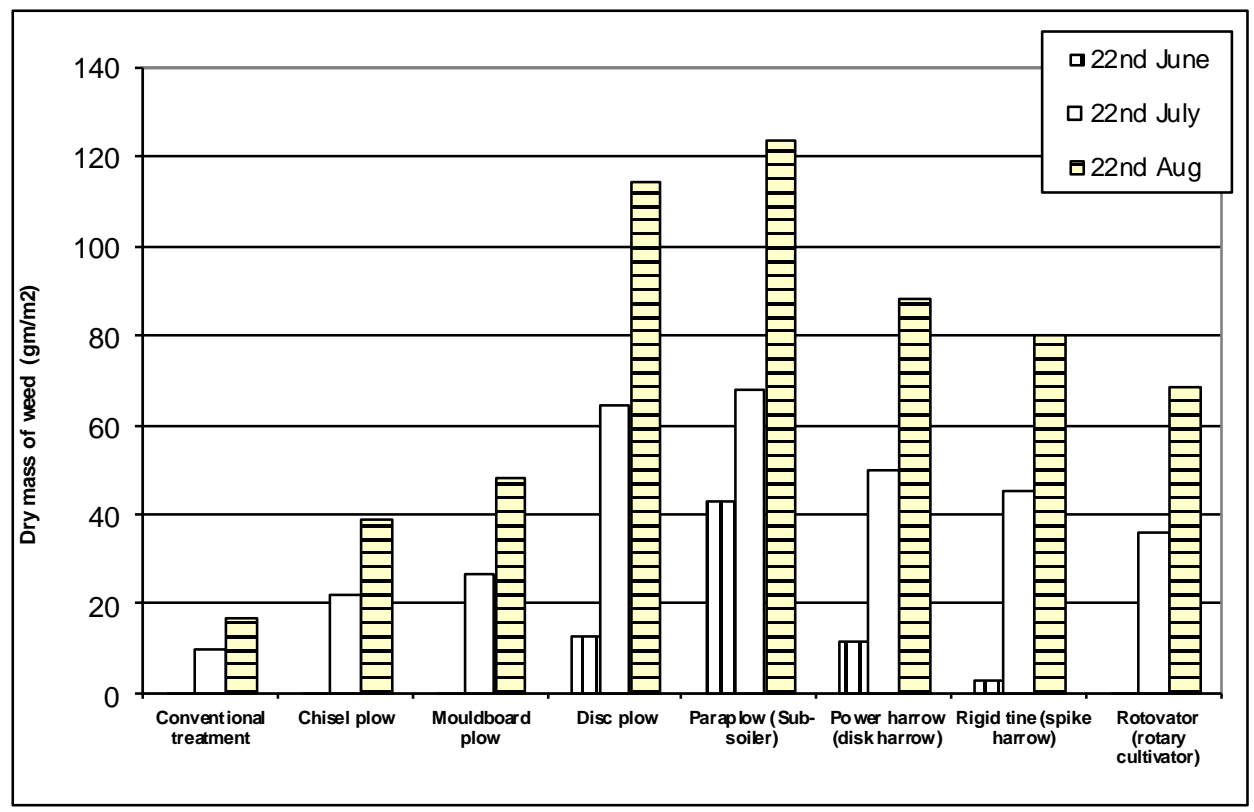

Fig. (3): Effect of tillage on dry mass of weed $\left(\mathrm{gm} / \mathrm{m}^{2}\right)$ 
Table (2): Effect of tillage on dry mass of weed $\left(\mathrm{gm} / \mathrm{m}^{2}\right)$ and crop yield.

\begin{tabular}{|c|c|c|c|c|}
\hline \multirow[b]{2}{*}{ Treatment } & \multicolumn{3}{|c|}{ dry mass of weed $(\mathrm{gm} / \mathrm{m} 2)$} & \multirow[b]{2}{*}{$\begin{array}{c}\text { crop yield } \\
\text { (kg/ha) }\end{array}$} \\
\hline & $\begin{array}{l}\text { 22nd } \\
\text { June }\end{array}$ & $\begin{array}{l}\text { 22nd } \\
\text { July }\end{array}$ & $\begin{array}{l}\text { 22nd } \\
\text { Aug }\end{array}$ & \\
\hline Conventional treatment & 0.12 & 9.78 & 17.12 & 39260 \\
\hline Chisel plow & 0.44 & 22.12 & 39.16 & 36010 \\
\hline Mouldboard plow & 0.65 & 26.61 & 48.62 & 34710 \\
\hline Disc plow & 12.72 & 64.28 & 114.78 & 24440 \\
\hline Paraplow (Sub-soiler) & 43.11 & 68.14 & 124.01 & 20410 \\
\hline Power harrow (disk harrow) & 11.9 & 50.09 & 88.51 & 27040 \\
\hline Rigid tine (spike harrow) & 3.13 & 45.18 & 80.32 & 28080 \\
\hline Rotovator (rotary cultivator) & 0.87 & 35.64 & 68.55 & 31070 \\
\hline L.S.D & & & & 3522 \\
\hline
\end{tabular}

\section{Crop yield:}

A significant yield reduction was found for both paraplow and disc plow treatments compared with the conventional tillage and chisel plow treatments. As shown in table (2). Yield losses were greater in paraplow treatment due to the large infestation of weeds. The crop yield values of corn silage under studied simulated implements were ranked as conventional treatment $>$ chisel plow $>$ mouldboard plow $>$ rotovator $>$ rigid tine spike $>$ power harrow $>$ disc plow $>$ paraplow. This trend might be attributed to the effective tillage depth increased the spreading of weed seeds vertically through the soil profile. The obtained results revealed that the crop yield values ranged between 20410 to 39260 under studied treatments, respectively with $\mathrm{LSD}_{05}$ value was 3522 . These results are in agreement with Khater, (2010).

\section{Relation between dry weed mass and crop yield:}

Simple correlation between the dry weed mass and yield was found which showed the effect of the weeds on the sorghum productivity as clarified in Fig.(4), with highly $\mathrm{R}^{2}$ of 0.98 . for all experimented implements.

\section{Cost benefit ratio:}

The costs of each treatment were claculated and given in Table (3). Fixed and variable costs within total production costs were calculated independently from each other. The maximum gross values of production were 13741 and $12603 \mathrm{LE} /$ ton for traditional and chisel plow treatments respectively which corporated with lower weed seeds amounts, table (2), while the minimum gross values of production were 8554 and 7143 
LE/ton for disc plow and paraplow respectively to the corresponding price which corporate with maximum weed seeds amounts, (350 LE/ton). Based on these results, the benefit-cost ratio was calculated to be, the maximum benefit cost ratio values were 2.60 and 2.62 for chisel plow and traditional treatment respectively, while the minimum benefit cost ratio values were 1.54 and 1.21 for disc plow and Paraplow respectively.

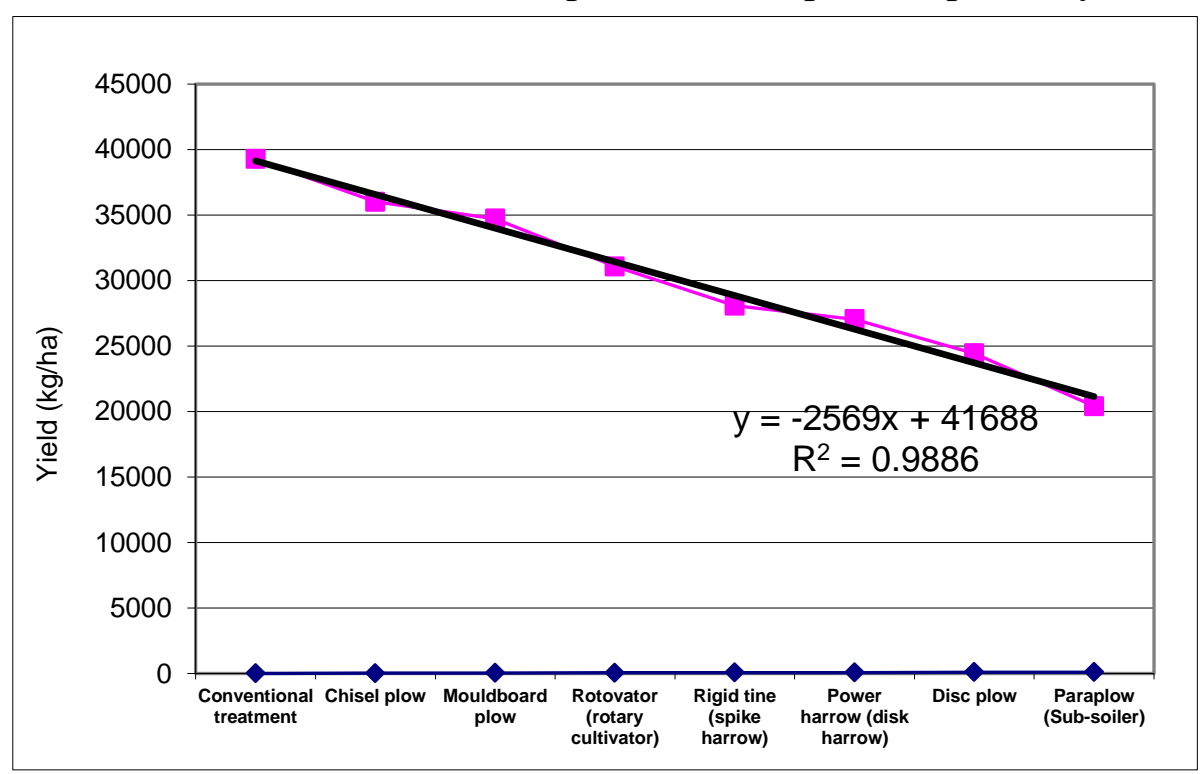

Fig. (4): Simple correlation between the dry weed mass and yield.

Table (3): Effect of tillage on benefit cost ratio.

\begin{tabular}{ccccccc}
\hline Treatment & $\begin{array}{c}\text { crop } \\
\text { yield } \\
\text { (ton/ha) }\end{array}$ & $\begin{array}{c}\text { sale price }(350 \\
\text { LE/ton) }\end{array}$ & $\begin{array}{c}\text { Variable } \\
\text { costs }\end{array}$ & $\begin{array}{c}\text { fixed } \\
\text { costs }\end{array}$ & $\begin{array}{c}\text { total } \\
\text { costs }\end{array}$ & BCR \\
\hline $\begin{array}{c}\text { Conventional } \\
\text { treatment }\end{array}$ & 39.26 & 13741 & 990 & 4250 & 5240 & 2.62 \\
\hline $\begin{array}{c}\text { Chisel } \\
\text { plow }\end{array}$ & 36.01 & 12603 & 895 & 3950 & 4845 & 2.60 \\
\hline $\begin{array}{c}\text { Mouldboard } \\
\text { plow }\end{array}$ & 34.71 & 12148 & 1050 & 4500 & 5550 & 2.18 \\
\hline $\begin{array}{c}\text { Disc } \\
\text { plow }\end{array}$ & 24.44 & 8554 & 1050 & 4500 & 5550 & 1.54 \\
\hline $\begin{array}{c}\text { Paraplow } \\
\text { (Sub-soiler) }\end{array}$ & 20.41 & 7143 & 1100 & 4800 & 5900 & 1.21 \\
\hline $\begin{array}{c}\text { Power harrow } \\
\text { (disk harrow) }\end{array}$ & 27.04 & 9464 & 990 & 4250 & 5240 & 1.80 \\
\hline $\begin{array}{c}\text { Rigid tine } \\
\text { (spike harrow) }\end{array}$ & 28.08 & 9828 & 990 & 4250 & 5240 & 1.87 \\
\hline
\end{tabular}




\section{CONCLUSION}

In order to validate the SeedChaser model, experimental results of Eight tillage implements were examined for estimation of the SeedChaser model including the conventional treatment which widely used in New El Salhia region (chiseling twice). The tillage implements were tested in field experiments and compare with data collected from estimation of the SeedChaser model. Tillage implements that were extrapolated were coded in the Java programming language which predicts the movement of weed seeds following a user selectable sequence of tillage events. Paraplow and disc plow showed a weed infestation which increased and appeared in few weeks later, compared with other tillage techniques. While a significant reduction in weed infestation during conventional tillage, and chisel plow treatments was occurred. In the $1^{\text {st }}$ period on $22^{\text {nd }}$ of June, no remarkable weeds infestation was happened, dry mass of the weeds was less than 45 $\left(\mathrm{g} / \mathrm{m}^{2}\right)$ in all treatments, on $22^{\text {nd }}$ of July, a remarkable existence of the weeds was found, it was less than $40\left(\mathrm{~g} / \mathrm{m}^{2}\right)$ for conventional, chisel, mouldboard and rotovator implements, while it was more than $64\left(\mathrm{~g} / \mathrm{m}^{2}\right)$ for both paraplow and disc plow. Through the last period on $22^{\text {nd }}$ August the weed infestation was clearly found, the paraplow and disc plow were represented the higher values as compared with the other techniques, it was more than $114\left(\mathrm{~g} / \mathrm{m}^{2}\right)$, while the conventional tillage treatment was represented by less than $15\left(\mathrm{~g} / \mathrm{m}^{2}\right)$. The crop yield values under studied simulated implements were ranked as conventional treatment $>$ chisel plow $>$ mouldboard plow $>$ rotovator $>$ rigid tine spike $>$ power harrow $>$ disc plow $>$ paraplow. The obtained results revealed that the crop yield values ranged between 20410 to 39260 under studied treatments, respectively. The SeedChaser model can be evaluated for the traditional treatment using the chisel plow in proficiency ranged between 0.9086 and 0.9312 for estimated and measured data respectively, while it was ranged between 0.7168 and 0.7450 for the mouldboard plow. In case of using the disc plow the proficiency was ranged between 0.7004 and 0.7063 for estimated and measured data respectively. A lower proficiency was found with using the Paraplow with results ranged between 0.6310 and 0.6916 
for estimated and measured data respectively, when it was ranged between 0.7245 and 0.7294 for the power harrow. The lowest proficiency was found when using the rigid tine, results were ranged between 0.5673 and 0.6032 for estimated and measured data respectively. When using the rotovator a high proficiency was ranged between 0.9050 and 0.9176 for estimated and measured data receptively. Generally, the SeedChaser model seems to be acceptable for predicting the weed seeds distribution with all used implements .

\section{REFERENCES}

Al-Kaisi M. and Yin X. (2004). Stepwise time response of corn yield and economic return to no tillage. Soil Till Res. 78:91-101.

Buhler D., Hartzler R. and Frank F. (1997). Implications of weed seedbank dynamics to weed management. Weed Sci. 45, 329-336.

Forcella F., Wilson R., Renner K., Dekker J., Harvey R., Alm D., Buhler, D. and Cardina, J. (1992). Weed seedbanks of the US corn belt: magnitude, variation, emergence and application. Weed Sci. 40, 636-644.

George O. and Frank F. (2006). Tillage effect on reproductive output by foxtail cohorts in corn and soybean. Weed Science, 54:419-427.

Govers G., Quine T., Desmet P. and Walling D. (1996). The relative contribution of soil tillage and overland flow erosion to soil redistribution on agricultural land. Earth Surf. Process. Landforms 21, 929-946.

Islam K., Mona M., Mladen T. and Mohamed K. (2007). Assessment of Conservation Tillage Techniques in Sugar Beet Production, pp 343-353. Status of Mediterranean Soil Resources: Actions needed to support their sustainable use. Tunis, Tunisia 26 - 31 May 2007.

Khater M. (2010). Comparison study between some minimum tillage systems in sandy loam soil. Egyptian. J. Appl. Sci., 20 (5): 286296 
Klute, A. (ed.) (1986). Methods of Soil Analysis. Part 1. Physical and Minerological Properties. Am. Soc. Agron. Inc., Agronomy Series 9. USA. $1173 \mathrm{pp}$.

Marshall E. and Brain P. (1999). The horizontal movement of seeds in arable soil by different soil cultivation methods. J. Appl. Ecol. 36, 443-454.

Mead A., Grundy A., Brain P. and Marshall E. (2003). Development of a model for the joint horizontal and vertical movement of seeds following cultivation. Aspects of Applied Biology 69, Seedbanks: Determination, dynamics and management, pp. 179-186.

Mohler C., Frisch J. and McCulloch C. (2006). Vertical movement of weed seed surrogates by tillage implements and natural processes. Soil Tillage Res. 86, 110-122.

O'Donovan J. and McAndrew D. (2000). Effect of tillage on weed populations. Weed Technol. 14:726-733.

Rahman A., James T., Mellsop J. and Grbavac N. (2000). Effect of cultivation methods on weed seed disturbance and seedling emergence. New Zealand Plant Prot. 53, 28-33.

Stahl L., Johnson G., Wyse D., Buhler D. and Gunsolus, J. (1999). Effect of tillage on timing of Setaria spp. emergence and growth. Weed Sci. 47, 563-570.

Staricka J., Allmaras R. and Nelson W.(1991). Spatial variation of crop residue incorporated by tillage. J. American Soc. Soil Sci. 55, $1668-1674$.

Swanton C., Shrestha A., Knezevic S., Roy R. and Ball-Coelho,B. (2000). Influence of tillage type on vertical weed seedbank distribution in a sandy soil. Can. J. Plant Sci. 80, 455-457.

Yenish J., Doll J. and Buhler D.(1992). Effects of tillage on vertical distribution and viability of weed seed in soil. Weed Sci. 40, 429433. 


\section{الملخص العربي \\ استخدام وتحقيق نموذج Seedchaser لتقييم دور الات الحراثة في توزيع الجيع التئي انتشار بذور الحشائش بمنطقة الصالحية الجديدة \\ * إسلام محمد منير خاطر}

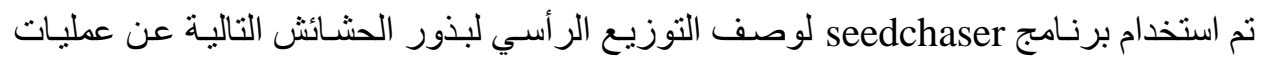
اعداد مرقد البذرة بمنطقة الصـالحية الجديدة وذلك للربط بين نوع الالاتة المستخدمة فى عملية

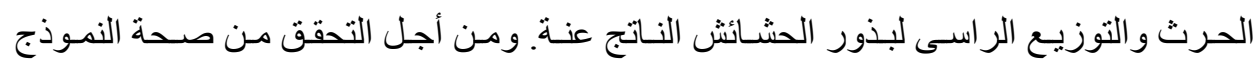
SeedChaser التقليدية المستخدمة على نطاق و اسع في منطقة الصـالحية الجديدة (المحر اث الحفار مرتين). تم اختبار ألات اعداد مرقد البذرة في التجارب الحقلية ومقارنتها مع البيانات التقديرية التي تم جمعها

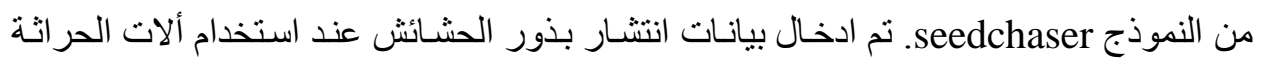

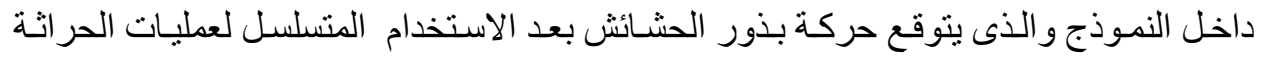
المختلفة. وقد اظهر استخدام كلا من محر اث تحت التربـة و المحر اث القرصى زئه زيادة فى انتشـار

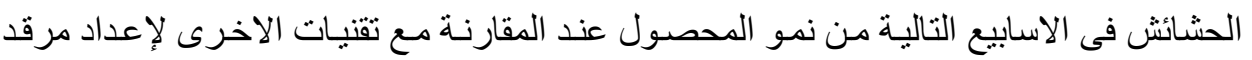

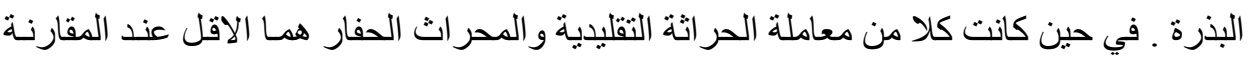

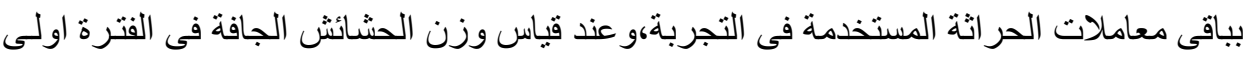

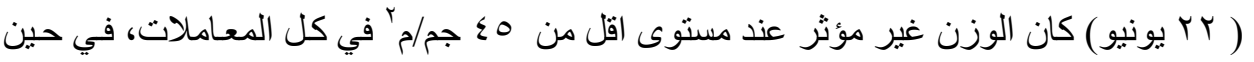

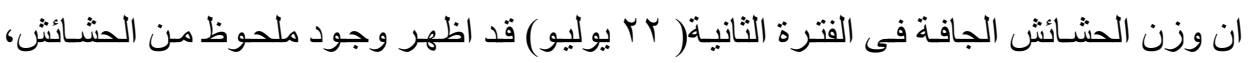

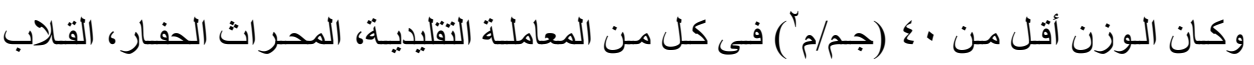

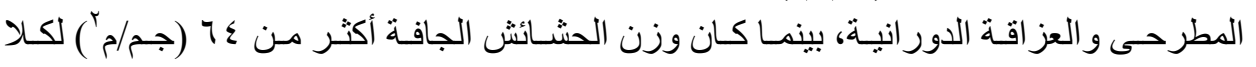

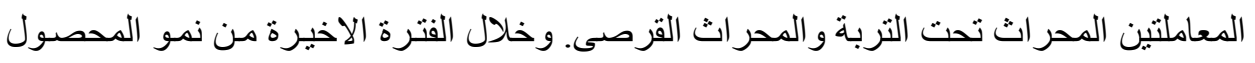

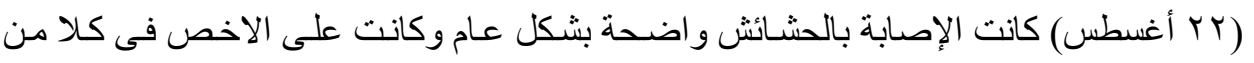

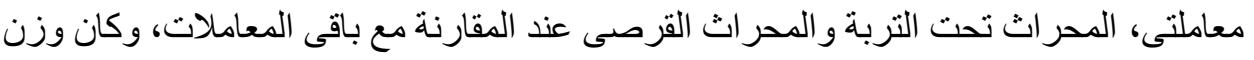

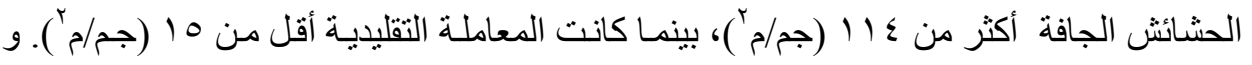

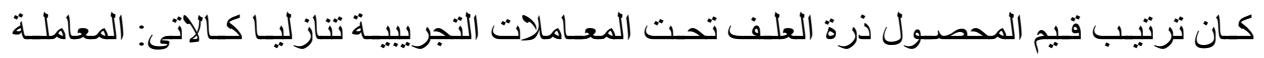

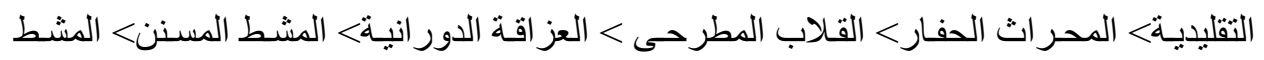

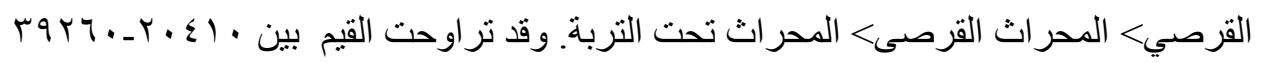

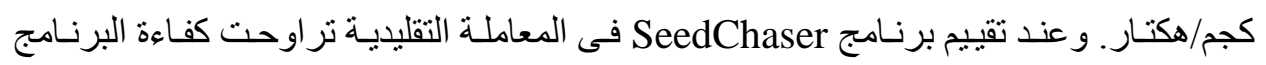

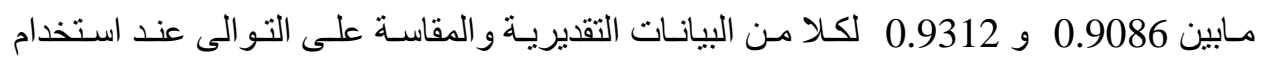
المحاريت الحفارة. بينما نر اوحت القيم مابين 0.7168 و 0.7450 عند استخدام المحر اث القلاب المطرحى.

*قم صيانة الار اضى- مركز بحوث الصحراء- القاهرة- مصر 
وفى حالـة استخدام المحر اث القلاب القرصى تراوحت الكفاءة مابين , 0.7004 و 0.7063

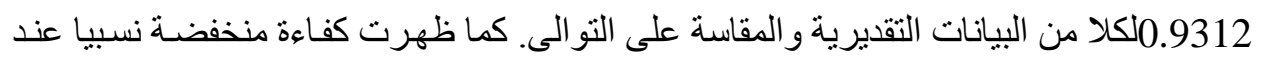

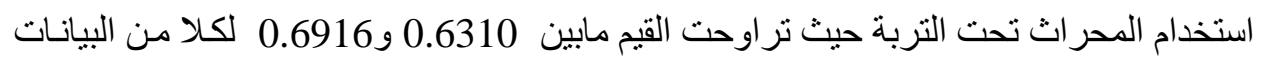

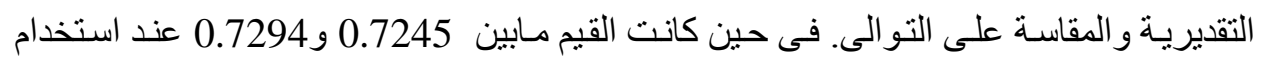

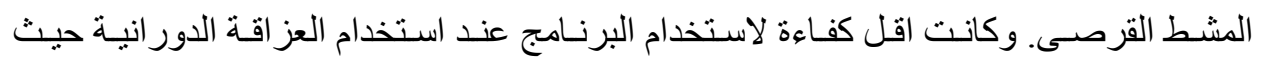

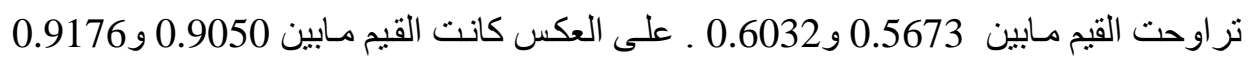

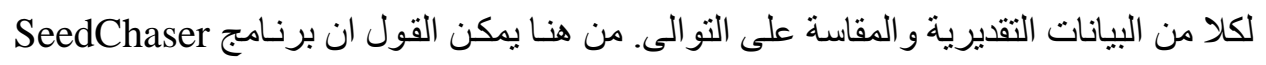

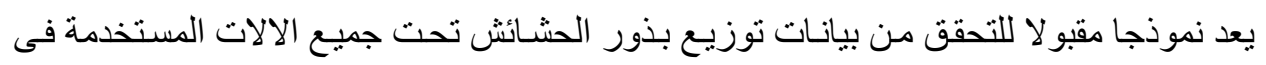

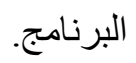

